CELL STRUCTURE AND FUNCTION 9, Suppl., s97-101 (1984)

(C) by Japan Society for Cell Biology

\title{
IV-2 The Cell Cycle
}

\author{
Masa-atsu Yamada and Fumio Hanaoka \\ Department of Physiological Chemistry, Faculty of Pharmaceutical Sciences, \\ University of Tokyo, Bunkyo-ku, Tokyo 113, Japan
}

Each living cell is at some point of the cell cycle; the $\mathrm{G}_{1}, \mathrm{~S}, \mathrm{G}_{2}, \mathrm{M}$ or $\mathrm{G}_{0}$ phase. Consequently, this section contains a variety of topics. Conversely, most of the chapters in this volume include some aspects of the cell cycle; therefore, our citations are restricted to studies that stress the cell cycle.

\section{Serum and growth factors}

Serum, a complex mixture of various substances, has been used routinely in culture media for animal cells to provide necessary growth factors. Growth factors are reviewed by Ohno and Okigaki in this volume.

Okuda and Kimura $(1978,1982)$ worked on the characteristics of rat $3 Y 1$ cells and found that growth of untransformed fibroblast cells in culture is regulated by factors in the serum and by cell density. They further studied the kinetics cf entry into $S$ phase after stimulation of resting $3 \mathrm{Y} 1$ cells by serum and suggested that the extremely asynchronous entry into $S$ phase at a low serum concentration is attributable to variability in the rates of events in the serum-requiring period, the traverse of which is presumably equivalent to the commitment to enter $\mathrm{S}$ phase (Okuda and Kimura, 1983).

In a mouse L cell system, Yamasaki and Ichihara $(1976,1977)$ examined the effects of cAMP, insulin, amino acids and serum on the induction of ornithine decarboxylase (ODC). They found that in nongrowing cells there is stable RNA which is involved in ODC induction, possibly the mRNA of ODC, and that the observed induction is caused by inhibition of enzyme degradation and accelerated translation, whereas in growing cells this RNA is unstable and ODC induction is controlled at the level of transcription. In the case of adult rat hepatocytes in primary culture, cells in $\mathrm{G}_{0}$ enter the $G_{1}$ phase density-dependently at first; then cells in the $G_{1}$ phase seem to be stimulated to enter the $\mathrm{S}$ phase by insulin and EGF, and a low density may permit cells after DNA synthesis to enter the $M$ phase (Tomita, Nakamura and Ichihara, 1981; Nakamura, Tomita and Ichihara, 1983).

In human diploid fibroblasts, Ohno and Kaneko (1981) showed that PDGF acts in a competitive manner with $\mathrm{Ca}^{2+}$ in the medium. Ohno (1982) presented data that suggests that calmodulin plays some role in these cells which become sufficiently "competent" to enter the S phase. Nishikawa and Okitsu (1979) found high activity for the completion of Balb/3T3 cell division and FGF-like activity in the extract of Rhodamine fibrosarcoma.

\section{Cell cycle mutants}

Mutants that are temperature-sensitive (ts) for growth and that are blocked at specific points in the cell cycle should aid in the identification of specific biochemical 
events in the cell cycle.

Nishimoto and his collaborators characterized a ts mutant of BHK21, tsBN2. The mutant showed premature chromosome condensation (PCC) upon a temperature shift to non-permissive temperature, and the synthesis of protein(s) for chromosome condensation was found to be regulated by the post-transcriptional mechanism (Nishimoto et al., 1981). Cell fusion experiments revealed that a "chromosome condensing factor(s)" is produced in tsBN2 cells that have PCC (Hayashi et al., 1982). At a non-permissive temperature, both histone $\mathrm{H} 1$ and $\mathrm{H} 3$ were phosphorylated extensively as in mitotic cells (Ajiro, Nishimoto and Takahashi, 1983). The mutant phenotype was reversed by DNA-mediated gene transfer of hamster and mouse DNA (Kai et al., 1983). Nishimoto et al. (1982) devised a simple method for cell fusion, isolated a number of ts mutants from BHK cells and classified them in 18 complementation groups. This kind of study is laborious, but certainly important and promising.

Yamada's group isolated a unique ts mutant, designated ts85, from a mouse mammary carcinoma cell line, FM3A. The mutant was arrested mainly in $\mathrm{G}_{2}$ phase and partly in $\mathrm{S}$ phase at a non-permissive temperature $\left(39^{\circ} \mathrm{C}\right)$ and was defective in chromosome condensation and DNA replication at $39^{\circ} \mathrm{C}$ (Mita et al., 1980). Matsumoto et al. (1980) found that ts 85 was defective in $\mathrm{H} 1$ histone phosphorylation at $39^{\circ} \mathrm{C}$. Synchronization studies suggested that $\mathrm{H} 1$ histone phosphorylation is involved in both DNA synthesis and chromosome condensation (Yasuda et al., 1981). Analysis of chromosomal proteins in ts 85 revealed that the disappearance of A24 protein (ubiquitinated $\mathrm{H} 2 \mathrm{~A}$ histone) at $39^{\circ} \mathrm{C}$ may be the primary defect in this mutant (Marunouchi et al., 1980; Matsumoto et al., 1983).

Sato and his associates isolated ts mutants from murine leukemic L5178Y cells. Ts 2 was found to be defective in both mitosis and cytokinesis (Shiomi and Sato, 1976). Cytofluorometric analysis indicated that unequal chromosome distribution among daughter nuclei took place during multinucleation (Shiomi and Sato, 1978). Another ts mutant, ts 39 , accumulated micronucleate cells at a non-permissive temperature (Sato and Hama-Inaba, 1978). Multinucleation started during the mitotic period and $G_{1}$-phase after exposure to a non-permissive temperature (Hama-Inaba, Tanaka and Sato, 1981).

Kimura and his associates isolated ts mutants from fibroblastic rat cells (3Y1) and assigned them to 8 complementation groups (Ohno and Kimura, 1984; Ohno et al., 1984). Five of eight mutants entered $S$ phase at a non-permissive temperature after infection with SV40, indicating that SV40 interacts closely with cellular ts lesions related to the control of proliferation and cell survival (Ohno and Kimura, 1983).

More recently, Ide, Ninomiya and Ishibashi (1983) succeeded in isolating a Go specific ts mutant from rat $3 Y 1$ cells. The characterization of this mutant will give us interesting information about the control mechanism of the cell cycle.

Other aspects of cell cycle

Kuroki (1981) found that intracutaneous injection of cholera toxin, exotoxin of Vibrio cholerae, into the back of mice induces two successive synchronous divisions of basal cells in the epidermis. This experimental system will provide a unique model for investigating not only the mechanism that controls functional and mitotic homeostasis in normal tissues but the possible association of various agents (e.g., carcinogens) with a specific cell cycle.

Neocarzinostatin (NCS), a polypeptide antibiotic with a molecular weight of 
10,700 that was isolated from Streptomyces carzinostaticus, has antitumor activities in various systems. Ebina et al. (1975a) demonstrated that NCS prevents cultured mammalian cells from progressing through the cell cycle, resulting in the arrest of cell growth at the $\mathrm{G}_{2}$ or the $\mathrm{G}_{1}$-early $\mathrm{S}$ phases. They (Ebina and Ishida, 1975b; Ebina, Satake and Ishida, 1977) have shown that NCS inhibits cap formation in Daudi cells, cell spreading of HeLa cells and the vinblastine-induced paracrystal formation of tubulin, the subunit protein of the microtubules. NCS also affects the membrane-microfilament system in addition to the membrane-microtubule system (Yahara et al., 1979). Caffeine was found to reduce the NCS effect on the inhibition of DNA synthesis and the induction of the $\mathrm{G}_{2}$ block (Iseki, Ebina and Ishida, 1980a). This indicates that the mechanism of the NCS-induced $\mathrm{G}_{2}$ block is related to that of the X-ray-induced $\mathrm{G}_{2}$ block (Iseki, Ebina and Ishida, 1980b).

Hyodo and his collaborators studied the response of mouse FM3A cells following DNA damage produced by treatment with 8-methoxypsoralen plus near-ultraviolet radiation. They found that the cell-cycle progression first was halted then, after several hours of incubation, the cells started to proceed with the cycle but were finally arrested at the $\mathrm{G}_{2}$ phase (Hyodo et al., 1982a). A rapid decrease in the incorporation of $\left[{ }^{3} \mathrm{H}\right]$ thymidine into DNA occurred initially, but this decrease was not due to a lowering of the rate of DNA chain elongation at the replication fork (Hyodo et al., 1982b), it was due to the inhibition of maturation of the Okazaki fragment to the intermediate DNA (Hyodo et al., 1983).

Cultured fibroblasts derived from Werner's syndrome (WS; adult progeria) patients have lower growth potentials than normal human fibroblasts. Takeuchi et al. (1982a) studied the cell cycle of WS fibroblasts and found that these cells showed prolongation of the $\mathrm{S}$ phase and whole cell cycle. This prolonged $\mathrm{S}$ phase in WS cells is due to the decreased frequency of replicon initiation (Takeuchi et al., 1982b), and SV40 infection of WS cells changed the frequency in WS cells toward that in normal cells (Hanaoka et al., 1983).

Nakamura and Okada (1979) studied the relationship between the timing of BUdR treatment and mutation rates of 6 markers in synchronized mouse L5178Y cells. Their data suggest that (1) genes responsible for asparagine independence, 6thioguanine resistance and excess thymidine resistance activity may be replicated in the early $\mathrm{S}$ period and the gene for methotrexate resistance activity in the middle $\mathrm{S}$ period, and (2) the mechanisms of mutation induction for the arabinosylcytosine resistance and ouabain resistance markers may be essentially different from those for the above four markers.

Ono and Okada (1981) compared DNase I digestability of DNA from mouse L5178Y cells, which had been labeled with $\left[{ }^{3} \mathrm{H}\right]$ thymidine at early, middle and late $\mathrm{S}$ phases. Their results indicate that most of the transcriptionally active DNA is replicated very early in the $\mathrm{S}$ phase.

Kuroda (1976) examined changes in cell-to-cell cohesive activity during the HeLa cell cycle in rotation culture and found that activity is highest in the $M$ phase, the second highest value being obtained in the early period of the $\mathrm{S}$ phase.

\section{REFERENCES}

Ajiro, S., Nishimoto, T. and Takahashi, T. (1983). J. Biol. Chem. 258, 4534-4538.

Ebina, T., Ohtsuki, K., Seto, M. and Ishida, N. (1975a). Eur. J. Cancer 11, 155-158. 
Ebina, T. and IsHidA, N. (1975b). Cancer Res. 35, 3705-3709.

Ebina, T., Satake, M. and Ishida, N. (1977). Cancer Res. 37, 4423-4429.

Hama-Inaba, H., Tanaka, T. and Sato, K. (1981). Cell Struct. Funct. 6, 231-244.

Hanaoka, F., Takeuchi, F., Matsumura, T., Goto, M., Miyamoto, T. and Yamada, M. (1983). Exp. Cell Res. 144, 463-467.

Hayashi, A., Yamamoto, S., Nishimoto, T. and Takahashi, T. (1982). Cell Struct. Funct. 7, 291294.

Hyodo, M., Fujita, H., Suzuki, K., Yoshino, K., Matsuo, I. and OhKido, M. (1982a). Mutation Res. 94, 199-211.

Hyodo, M., Hori, T., Kanno, S., Zanma, T. and Suzuki, K. (1983). Biochim. Biophys. Acta 740, 46-51.

Hyodo, M., Zanma, T., Hori, T., Yoshino, K. and Suzuki, K. (1982b). Biochim. Biophys. Acta 699, 164-169.

Ide, T., Ninomiya, J. and Ishibashi, S. (1984). Exp. Cell Res. 150, 60-67.

IsEKi, S., Ebina, T. and IshidA, N. (1980a). Cancer Res. 40, 3786-3791.

IseKi, S., Ebina, T. and IshidA, N. (1980b). Gann 71, 567-571.

Kai, R., Sekiguchi, T., Yamashita, K., Sekiguchi, M. and Nishimoto, T. (1983). Somat. Cell Genet. 9, 673-680.

Kuroda, Y. (1976). Ann. Report of Natl. Instit. Genet. No. 26, p. 30.

Kuroki, T. (1981). Proc. Natl. Acad. Sci. USA 78, 6958-6962.

Marunouchi, T., Yasuda, H., Matsumoto, Y. and Yamada, M. (1980). Biochem. Biophys. Res. Commun. 95, 126-131.

Matsumoto, Y., Yasuda, H., Marunouchi, T. and Yamada, M. (1983). FEBS Lett. 151, 139-142.

Matsumoto, Y., Yasuda, H., Mita, S., Marunouchi, T. and Yamada, M. (1980). Nature 284, 181-183.

Mita, S., Yasuda, H., Marunouchi, T., Ishiko, S. and Yamada, M. (1980). Exp. Cell Res. 126, 407-416.

Nakamura, N. and OKada, S. (1979). Mutation Res. 60, 83-89.

Nakamura, T., Tomita, Y. and Ichihara, A. (1983). J. Biochem. 94, 1029-1035.

Nishikawa, K. and Okitsu, C. (1979). Cold Spring Harbor Conferences on Cell Proliferation 6, 441-452.

Nishimoto, T., Ishida, R., Ajiro, K., Yамамото, S. and Takahashi, T. (1981). J. Cell. Physiol. 109, 299-308.

Nishimoto, T., Sekiguchi, T., Kai, R., Yamashita, K., Takahashi, T. and Sekiguchi, M. (1982). Somat. Cell Genet. 8, 811-824.

Ohno, K. and Kimura, G. (1984). Somat. Cell Genet. 10, 29-36.

Ohno, K., Okuda, A., Ohtsu, M. and Kimura, G. (1984). Somat. Cell Genet. 10, 17-28.

Oнno, T. (1982). International Congress Series No. 598, 234-238.

Ohno, T. and KaneKo, I. (1981). Cell Struct. Funct. 6, 83-86.

Okuda, A. and Kimura, G. (1978). Exp. Cell Res. 111, 55-62.

Okuda, A. and Kimura, G. (1982). J. Cell. Physiol. 110, 267-270.

Okuda, A. and Kimura, G. (1983). Exp. Cell Res. 145, 155-165.

Ono, T. and OKada, S. (1981). Biochim. Biophys. Acta 655, 113-116.

Sato, K. and Hama-Inaba, H. (1978). Exp. Cell Res. 114, 484-486.

Shiomi, T. and Sato, K. (1976). Exp. Cell Res. 100, 297-302.

Shiomi, T. and Sato, K. (1978). Cell Struct. Funct. 3, 95-102.

Takeuchi, F., Hanaoka, F., Goto, M., Yamada, M. and Miyamoto, T. (1982a). Exp. Gerontol. 17, 473-480.

Takeuchi, F., Hanaoka, F., Goto, M., Akaoka, I., Hori, T., Yamada, M. and Miyamoto, T. (1982b). Hum. Genet. 60, 365-368.

Tomita, Y., Nakamura, T. and Ichihara, A. (1981). Exp. Cell Res. 135, 363-371.

Yahara, I., Iwashita, S., Ebina, T., SAtake, M. and Ishida, N. (1979). Cancer Res. 39, 46874693. 
YAmASAKi, Y. and IchihaRA, A. (1976). J. Biochem. 80, 557-562.

YAMASAKI, Y. and ICHIHARA, A. (1977). J. Biochem. 81, 461-465.

Yasuda, H., Matsumoto, Y., Mita, S., Marunouchi, T. and Yamada, M. (1981). Biochemistry 20, 4414-4419. 